\title{
Benign Brain Stem Neoplasm
}

National Cancer Institute

\section{Source}

National Cancer Institute. Benign Brain Stem Neoplasm. NCI Thesaurus. Code C8549.

A benign neoplasm that arises from the brain stem. 